\title{
Improvement of Glucose Homeostasis in Insulin-dependent Diabetics Using a Miniature Insulin Infusion Pump with a Fixed Profile
}

\author{
K. Kølendorf ${ }^{1}$, J. Bojsen ${ }^{2}$, and B. Lørup ${ }^{1}$ \\ ${ }^{1}$ Steno Memorial Hospital, Gentofte and ${ }^{2}$ The Finsen Laboratory, The Finsen Institute, Copenhagen, Denmark
}

\begin{abstract}
Summary. Glucose homeostasis was studied in nine longstanding insulin-dependent diabetic patients using a portable pump for intravenous insulin infusion. The $24 \mathrm{~h}$ infusion dose was calculated from the conventional SC insulin treatment. The range of basal infusion rates was 2.5 to $15 \mathrm{mU} / \mathrm{min}$ and peak delivery rates were raised up to 16-fold from start of main meals for 30-60 minutes. Mean blood glucose improved from $12.0 \pm 2.4$ to $6.4 \pm 1.0 \mathrm{mmol} / \mathrm{l}(\mathrm{SD})$ during infusion $(\mathrm{p}<0.01)$. Glucose excretion decreased from $23 \mathrm{~g} / 24 \mathrm{~h}$ (range $1-42$ ) to $4 \mathrm{~g} / 24 \mathrm{~h}$ (range $0-14)(\mathrm{p}<0.01)$. Mean amplitude of glycaemic excursions was significantly improved during infusion (from $8.9 \pm 4.8$ to $4.7 \pm 0.9 \mathrm{mmol} / 1 ; \mathrm{p}<$ 0.01 ). No severe hypoglycaemic episodes or other adverse reactions were seen.
\end{abstract}

Key words: Portable insulin infusion pump, preprogrammed IV insulin infusion, control of blood glucose, insulin-dependent diabetics.

Strict control of blood sugar is accompanied by a reduction in microvascular complications $[5,10,11$, 23]. Long term normoglycaemia is rarely achieved, however, with conventional subcutaneous insulin treatment. In order to mimic the physiological insulin secretion pattern by delivering small amounts of the hormone intravenously, two types of devices have been used: A glucose-controlled insulin and glucose delivery apparatus (the "artificial endocrine pancreas") $[1,12,15]$, and a simpler system consisting of a pump, which can deliver insulin at different rates, but without glucose sensing and servo-control mechanism $[2-4,7-9,13,20]$. Continuous subcutaneous insulin infusion with a portable pump has also been shown to be able to improve blood glucose control [16-18, 21, 22].

The aim of the present study was to show if preprogrammed intravenous insulin infusion with a 16rate portable pump could result in normalisation of the $24 \mathrm{~h}$ blood glucose profile in longstanding and insulin-dependent diabetic patients.

\section{Patients and Methods}

\section{Patients}

Nine patients with juvenile-onset insulin-dependent diabetes mellitus ( 4 males and 5 females) were studied after informed consent had been obtained. Clinical details are shown in Table 1. None of the diabetics suffered from any other illness at the time of the study or was taking any medication other than insulin. Mean age of the patients was 39 years with an average duration of diabetes of 16 years. All had grossly normal renal function (no proteinuria and normal serum creatinine values). Three patients had neuropathy, and seven had background retinopathy.

Endogenous insulin production was estimated by determining human plasma C-peptide in the fasting state (three times) and 2, 4, $6,8,10,15$ and $20 \mathrm{~min}$ after intravenous injection of $1.0 \mathrm{mg}$ glucagon [6]. No C-peptide could be detected in any patient. All patients had been treated with highly purified porcine NPH insulin (Insulin Leo Retard RI ${ }^{\circledR}$ ) twice daily for several years. Seven patients mixed NPH with short acting insulin (Insulin Leo Neutral $\mathrm{RI}^{\circledR}$ ) in the morning. The insulin requirement varied between 0.17 and $1.24 \mathrm{U} / \mathrm{kg}$ body weight.

\section{Insulin-delivery System}

Insulin was administered by a portable, battery-driven infusion pump. The impulse-controlled infusion system consists of a $250 \mathrm{~g}$ programmable electronic unit $(16 \times 9 \times 2 \mathrm{~cm})$ carried in a belt round the waist and an electromechanical syringe infuser $(250 \mathrm{~g})$ (Fig. 1) containing a $10 \mathrm{ml}$ plastic syringe $(18 \times 10 \times 2 \mathrm{~cm})$ carried in a pocket on the upper arm. The units are interconnected by a thin flexible cable. The system can be manually preprogrammed by pinconnectors in a miniature X-Y matrix board as a fixed $24 \mathrm{~h}$ 
Table 1. Individual data of 9 juvenile-onset insulin-dependent diabetics

\begin{tabular}{|c|c|c|c|c|c|c|c|}
\hline $\begin{array}{l}\text { Case } \\
\text { no. }\end{array}$ & Sex & $\begin{array}{l}\text { Age } \\
\text { (years) }\end{array}$ & $\begin{array}{l}\text { Duration of } \\
\text { diabetes } \\
\text { (years) }\end{array}$ & $\begin{array}{l}\text { Weight } \\
(\mathrm{kg})\end{array}$ & $\begin{array}{l}\text { Weight } \\
\text { (percent } \\
\text { ideal) }{ }^{\mathrm{a}}\end{array}$ & $\begin{array}{l}\text { Retinop- } \\
\text { athy }\end{array}$ & $\begin{array}{l}\text { Insulin dose } \\
\text { (U/24 h) }\end{array}$ \\
\hline 1 & $\mathbf{M}$ & 35 & 10 & 81.0 & 102 & - & 32 \\
\hline 2 & $\mathbf{M}$ & 54 & 19 & 81.0 & 119 & + & 52 \\
\hline 3 & $\mathrm{M}$ & 34 & 14 & 74.5 & 97 & + & 36 \\
\hline 4 & $\mathrm{~F}$ & 34 & 23 & 58.6 & 91 & + & 10 \\
\hline 5 & $\mathrm{~F}$ & 41 & 19 & 52.2 & 88 & + & 32 \\
\hline 6 & $\mathrm{~F}$ & 25 & 21 & 61.6 & 99 & + & 52 \\
\hline 7 & M & 54 & 19 & 84.0 & 123 & + & 62 \\
\hline 8 & $\mathrm{~F}$ & 38 & 5 & 50.2 & 78 & - & 62 \\
\hline 9 & $F$ & 34 & 13 & 56.0 & 91 & + & 28 \\
\hline mean & $4 \mathrm{M}$ & 39 & 16 & 66.6 & 99 & $7 / 9$ & 41 \\
\hline$\pm \mathrm{SD}$ & $5 F$ & 10 & 6 & 13.5 & 14 & & 18 \\
\hline
\end{tabular}

a The percent ideal body weight was calculated from the Tables of Natvig [14]. The IV infused insulin dose was identical to that of the last day of conventional SC insulin treatment

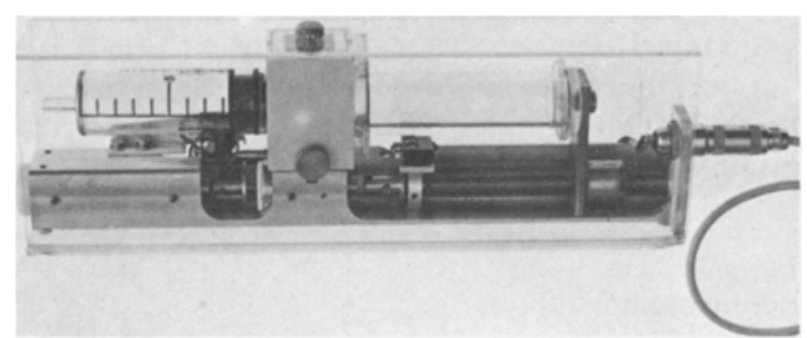

Fig. 1. The electromechanical syringe pump with a $10 \mathrm{ml}$ plastic syringe

profile. Sixteen rates can be programmed as a function of 48 halfhour intervals. The infusate volume is 48 to $768 \mu \mathrm{l} / \mathrm{h}$. The portable pump has been described in detail elsewhere [2].

Insulin Leo Neutral RI ${ }^{13}$ was dissolved in isotonic phosphate/ sodium chloride solution $(0.154 \mathrm{~mol} / 1)$ with human albumin $10 \mathrm{mg} / \mathrm{ml}, \mathrm{pH} 7.4$.

\section{Experimental Design}

The patients received a diet of $7459 \pm 428$ kjoule including about $150 \mathrm{~g}$ carbohydrate per day, divided into three main meals (at $0800 \mathrm{~h}, 1200 \mathrm{~h}$ and $1800 \mathrm{~h}$ ) and two snacks (at $1400 \mathrm{~h}$ and $2100 \mathrm{~h}$ ). Twenty per cent of the carbohydrate was given at $0800 \mathrm{~h}$, $25 \%$ at $1200 \mathrm{~h}$ and $1800 \mathrm{~h}$, and $15 \%$ at $1400 \mathrm{~h}$ and $2100 \mathrm{~h}$. Patients were fully mobile throughout the study, performing exercise three times daily for half an hour on a bicycle ergometer at $1030 \mathrm{~h}, 1500 \mathrm{~h}$ and $1830 \mathrm{~h}$. Diet and exercise were standardized on all days.

Attempts were made to get the best possible control on twice daily SC insulin during hospitalization. After about five days NPHinsulin treatment was stopped and short acting insulin given 4 times daily subcutaneously for $36 \mathrm{~h}$ in order to achieve a more physiological plasma insulin concentration during the 3 chief meals. Of the total daily insulin requirement, about $30 \%$ was given at $0700 \mathrm{~h}$, about $25 \%$ at $1200 \mathrm{~h}$, about $30 \%$ at $1800 \mathrm{~h}$ and about $15 \%$ at $2400 \mathrm{~h}$.

The IV insulin infusion was started between $1500 \mathrm{~h}$ and $1900 \mathrm{~h}$ through an indwelling teflon catheter in the forearm, and an over- night infusion period until $0800 \mathrm{~h}$ was carried out, so that the runin period would bring blood glucose into approximately the normal range. Seven diabetics were studied for $48 \mathrm{~h}$ and two for $36 \mathrm{~h}$ after the run-in period. To achieve better control however, the fixed programme was changed after $24 \mathrm{~h}$ in some patients.

The $24 \mathrm{~h}$ infusion dose for each patient was calculated from that patient's total daily insulin dosage on the last day of conventional SC insulin therapy. Insulin infusion with the portable infusion pump was preprogrammed according to the following guidelines: Between $0800 \mathrm{~h}$ and $1000 \mathrm{~h} 22 \%$ of the total daily insulin dose was infused, between $1000 \mathrm{~h}$ and $1200 \mathrm{~h} 8 \%$, between $1200 \mathrm{~h}$ and $1400 \mathrm{~h} 15 \%$, between 1400 and $1600 \mathrm{~h} 8 \%$, between $1600 \mathrm{~h}$ and $1800 \mathrm{~h} 5 \%$, between $1800 \mathrm{~h}$ and $2000 \mathrm{~h} 18 \%$, between $2000 \mathrm{~h}$ and $2230 \mathrm{~h} 9 \%$ and between $2230 \mathrm{~h}$ and $0800 \mathrm{~h} 15 \%$. The range of basal infusion rates were 2.5 to $15.0 \mathrm{mU} / \mathrm{min}$ and was given from $2230 \mathrm{~h}$ to $0600 \mathrm{~h}$, from $1000 \mathrm{~h}$ to $1200 \mathrm{~h}$, from $1530 \mathrm{~h}$ to $1600 \mathrm{~h}$, from $1730 \mathrm{~h}$ to $1800 \mathrm{~h}$, and from $1930 \mathrm{~h}$ to $2000 \mathrm{~h}$. The peak levels were raised up to sixteen fold and given for 30-60 min from the start of each main meal.

Capillary blood was drawn from earlobes every hour during the day and every 2 hours at night during NPH insulin treatment and 31 times daily during SC short acting insulin and IV infusion. Whole blood glucose was measured by the glucose oxidase method ( $\left.\mathrm{Kabi}^{(\mathrm{Q}}\right)$, as was glucose excretion in $24 \mathrm{~h}$ urine samples. $24 \mathrm{~h}$ calculations were made for mean blood glucose (MBG). The mean amplitude of glycaemic excursions (MAGE) served as a measure of instability of the diabetes regulation [19]. Hypoglycaemic reactions were recorded when the patient had appropiate symptoms and blood glucose levels were lower than $2.5 \mathrm{mmol} / 1$. MBG and MAGE in nondiabetics were calculated from 31 capillary blood glucose measurements in 15 persons $20-50$ years of age (mean 29 \pm 12 ).

For statistical evaluation the Wilcoxon's Matched-pair sign test (two-tailed) was used. The results are given as mean $\pm \mathrm{SD}$.

\section{Results}

All patients felt well. In two cases phlebitis appeared and infusion had to be stopped approximately $36 \mathrm{~h}$ after the run-in period. Table 2 compares the MGB and glucose excretion on the control and infusion 
Table 2. Individual capillary mean blood glucose (mean $\pm \mathrm{SD}$ ) and glucose excretion on control days (NPH and short acting insulin, respectively) and on IV infusion day, and minimal and maximal blood glucose values during IV infusion. Capillary blood was taken every 1 to $2 \mathrm{~h}$ for glucose measurement during NPH insulin and 31 times daily during SC short acting insulin and IV infusion

\begin{tabular}{|c|c|c|c|c|c|c|c|}
\hline \multirow[b]{2}{*}{$\begin{array}{l}\text { Case } \\
\text { no. }\end{array}$} & \multicolumn{3}{|c|}{ Mean blood glucose $(\mathrm{mmol} / \mathrm{l})$} & \multicolumn{3}{|c|}{ Glucosuria $(\mathrm{g} / 24 \mathrm{~h})$} & \multirow[b]{2}{*}{$\begin{array}{l}\text { Range of } \\
\text { blood glucose } \\
\text { during IV infusion } \\
\text { mmol/1 }\end{array}$} \\
\hline & $\mathrm{NPH}$ & $\begin{array}{l}\text { Short-acting } \\
\text { SC }\end{array}$ & $\begin{array}{l}\text { Short-acting } \\
\text { IV }\end{array}$ & $\mathrm{NPH}$ & $\begin{array}{l}\text { Short-acting } \\
\text { SC }\end{array}$ & $\begin{array}{l}\text { Short-acting } \\
\text { IV }\end{array}$ & \\
\hline 1 & $16.2 \pm 2.7$ & $11.3 \pm 2.1$ & $7.1 \pm 1.4$ & 37 & 5 & 4 & 4.4 to 11.9 \\
\hline 2 & $15.4 \pm 0.5$ & $9.2 \pm 3.3$ & $6.2 \pm 1.5$ & 42 & 3 & 0 & 4.1 to 9.8 \\
\hline 3 & $10.7 \pm 4.9$ & $8.9 \pm 2.3$ & $5.8 \pm 1.9$ & 30 & 10 & 3 & 2.0 to 9.9 \\
\hline 4 & $12.8 \pm 2.2$ & $7.6 \pm 2.8$ & $6.5 \pm 2.8$ & 26 & 0 & 0 & 2.5 to 11.3 \\
\hline 5 & $10.0 \pm 7.0$ & $9.4 \pm 4.8$ & $6.4 \pm 2.7$ & 11 & 15 & 14 & 2.3 to 12.2 \\
\hline 6 & $9.5 \pm 2.0$ & $9.1 \pm 2.0$ & $6.3 \pm 2.2$ & 12 & 2 & 4 & 3.1 to 10.9 \\
\hline 7 & $11.1 \pm 3.0$ & $10.9 \pm 2.2$ & $5.7 \pm 2.2$ & 18 & 15 & 0 & 2.8 to 10.5 \\
\hline 8 & $10.6 \pm 2.8$ & $9.6 \pm 3.4$ & $8.4 \pm 2.2$ & 32 & 39 & 12 & 4.0 to 11.6 \\
\hline 9 & $11.4 \pm 3.6$ & $6.8 \pm 6.0$ & $5.0 \pm 2.7$ & 1 & 8 & 0 & 1.7 to 11.4 \\
\hline Mean & 12.0 & 9.2 & 6.4 & 23 & 11 & 4 & 3.0 to 11.1 \\
\hline$\pm \mathrm{SD}$ & 2.4 & 1.4 & 1.0 & 14 & 12 & 5 & 1.0 to 0.8 \\
\hline
\end{tabular}

days showing in all diabetics an improvement of the diabetic control during infusion. The MBG improved from $12.0 \pm 2.4 \mathrm{mmol} / 1$ during the NPH day, and 9.2 \pm 1.4 on the SC short acting insulin $(\mathrm{p}<0.01)$, respectively, to $6.4 \pm 1.0 \mathrm{mmol} / \mathrm{l}$ during infusion $(\mathrm{p}$ $<0.01)$. Glucose excretion was significantly lower during infusion $(\mathrm{p}<0.01)$. Ketonuria was not found.

Figure 2 shows a comparison of $\mathrm{MBG}$ and MAGE values of the individual patient on the experimental days. The MBG of the infusion day was significantly higher than the MBG of a comparable normal control group $(4.4 \pm 0.4 \mathrm{mmol} / \mathrm{l})(\mathrm{p}<0.01)$. MAGE was not significantly affected by the change to short acting insulin four times daily ( $8.9 \pm$ $4.8 \mathrm{mmol} / 1$ to $7.4 \pm 3.6 \mathrm{mmol} / \mathrm{l}$ ), however, during insulin infusion MAGE improved significantly to 4.7 $\pm 0.9 \mathrm{mmol} / 1(\mathrm{p}<0.01)$. MAGE on the infusion day, however, was significantly greater $(\mathrm{p}<0.001)$ in diabetic patients as compared to normals (1.8 \pm $0.6 \mathrm{mmol} / 1)$.

Figure 3 illustrates the blood glucose profile of patient 7 during IV infusion of $62 \mathrm{U} / 24 \mathrm{~h}$. It can be seen that near normal glucose profiles were obtained. Severe hypoglycaemic episodes were not seen. Only $1.7 \%$ of all blood glucose determinations were less than $2.5 \mathrm{mmol} / 1$ on the infusion day. The maximum and minimum glucose levels are given in Table 2.

\section{Discussion}

Better metabolic control in diabetic patients has been demonstrated using open-loop systems for IV infusion of insulin $[2,4,7-9,13,20]$, and for SC infusion

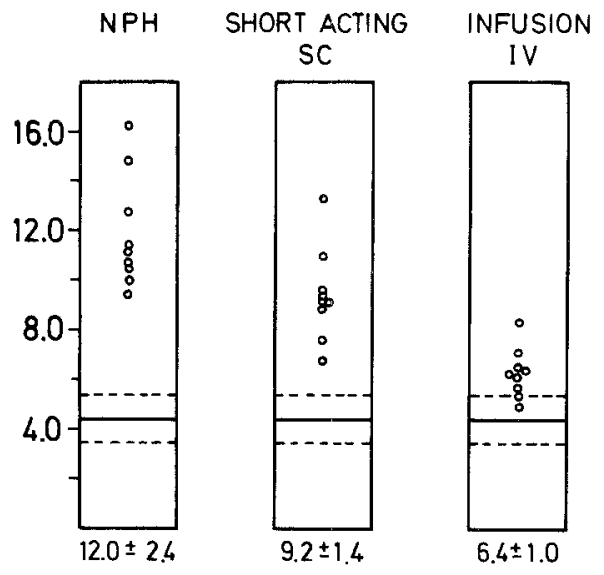

$M B G(\mathrm{mmol} / \mathrm{l})$
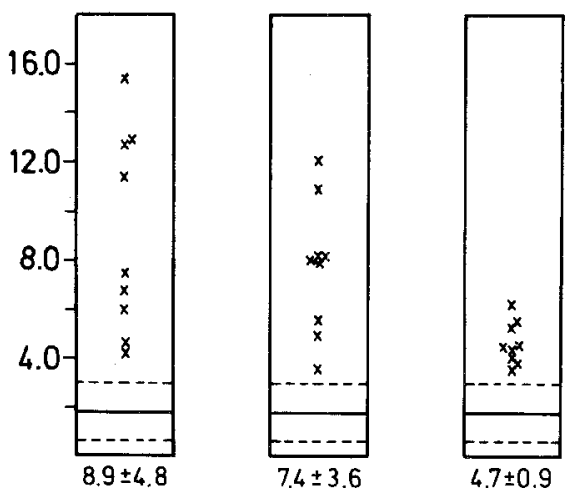

MAGE ( $\mathrm{mmol} / \mathrm{l})$

Fig. 2. Capillary blood glucose (top) and mean amplitude of glycaemic excursions (MAGE) (bottom) of the individual patients during: Conventional insulin twice daily; short acting insulin SC four times daily; and IV insulin infusion. Solid and dotted lines represent mean $\pm 2 \mathrm{SD}$ of the control group 

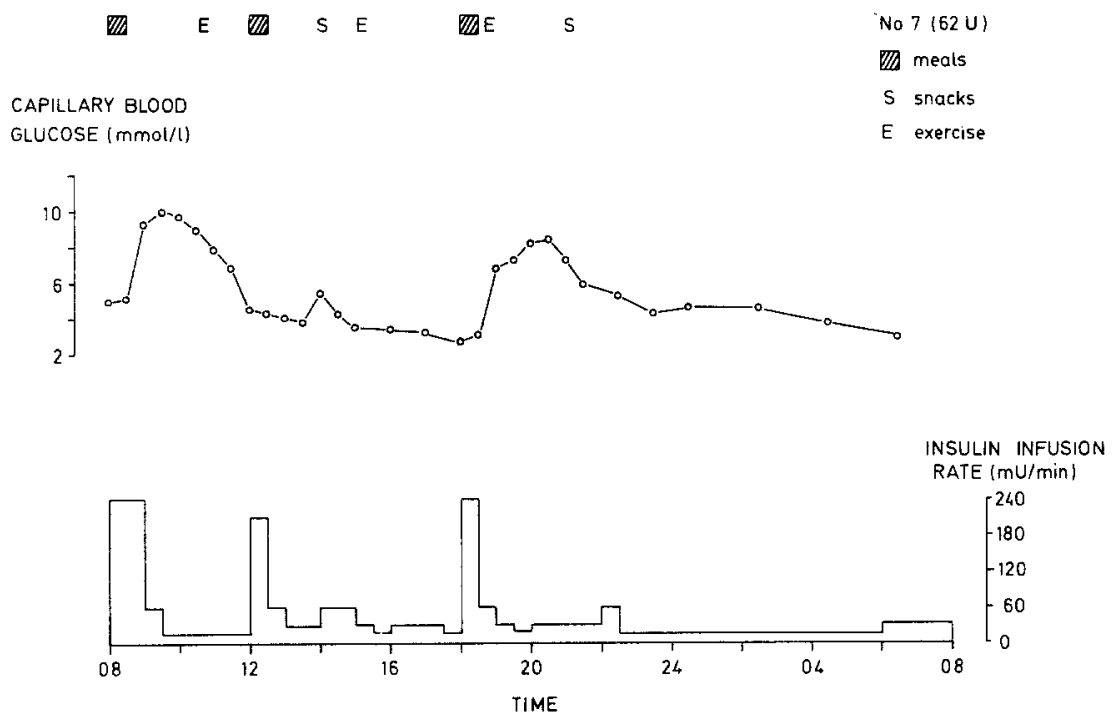

Fig. 3. Capillary blood glucose levels in a longstanding, insulin-dependent diabetic patient during IV insulin infusion with the portable pump. The SC calculated insulin dose $(62 \mathrm{U} / 24 \mathrm{~h})$ was used for infusion. The insulin infusion rate varied between 15 and $240 \mathrm{mU} / \mathrm{min}$. Meals (hatched area), snacks (S) and exercise (E) are shown at the top of the figure
[16-18, 21, 22], respectively. Preplanned IV insulin infusion with the open-loop delivery system used in this study appeared capable of improving the metabolic control of most diabetic patients. Overall blood glucose values were lower with IV infusion than with SC injections. The MBG, however, was not normoglycaemic during the short-term infusion.

With the preplanned programme comprising basal, peak and intermediate infusion rates, lowering of blood glucose towards normal values did not require a greater amount of insulin than had previously been administered by conventional means. This is of special interest as none of the diabetic patients had endogenous insulin secretion, and thus could not contribute essentially to the improvement of blood glucose regulation. The maximal infusion rate of insulin was chosen after having observed a similar increase in 5 insulin-dependent diabetic patients with no endogenous insulin secretion - connected to the Biostator ${ }^{\circledR}$ (unpublished results). The peak delivery rate was given from start of main meals so that plasma insulin concentration would rise before absorption of food.

The short-term peak rate and the intermediate rates resulted in fewer hypoglycaemic episodes. A constant basal rate of insulin was maintained overnight in order to produce a normal fasting glucose concentration. In accordance with previous observations $[4,8,12]$ an increased insulin requirement was found during the morning hours, so from $0600 \mathrm{~h}$ the insulin rate was doubled.

Recently results from patient-controlled insulin infusion pumps (Siemens) have been published [9, 13]. Control of blood glucose was similar to our findings. Endogenous insulin secretion was not investi- gated however, and probably existed in some cases [9]. We believe that in diabetic patients with no endogenous insulin secretion at least three rates of infusion are needed for normalisation of blood glucose values.

\section{References}

1. Albisser AM, Leibel B S, Ewart T G, Davidovac Z, Botz CK, Zingg W, Schipper H, Gander R (1974) Clinical control of diabetes by artificial pancreas. Diabetes 23: 397-404

2. Bojsen J, Kølendorf K, Haslev F, Jørgensen K (1978) A portable infusion pump, programmable with 16-rates. Biotelemetry 5: 123-133

3. Botz CK, Marliss E B, Albisser AM (1979) Blood glucose regulation using closed- and open-loop insulin delivery systems. Diabetologia 17: 45-49

4. Deckert T, Lørup B (1976) Regulation of brittle diabetics by a pre-planned insulin infusion programme. Diabetologia 12: 573-579

5. Engermann R, Bloodworth J MB Jr, Nelson S (1977) Relationship of microvascular disease in diabetes to metabolic control. Diabetes 26: 760-769

6. Faber OK, Binder C (1977) C-peptide response to glucagon. Diabetes 26: 605-610

7. Genuth S, Martin P (1977) Control of hyperglycaemia in adult diabetics by pulsed insulin delivery. Diabetes 26 : $571-581$

8. Hepp KD, Renner R, Funcke HJvon, Mehnert H (1977) Glucose homeostasis under continuous intravenous insulin therapy in diabetics. Horm Metab Res [Suppl] 7: 72-76

9. Irsigler K, Kritz H (1979) Long-term continuous intravenous insulin therapy with a portable insulin dosage-regulating apparatus. Diabetes 28: 196-203

10. Job D, Eschwege E, Guyot-Argenton C, Aubry TP, Tchobroutsky $G$ (1976) Effect of multiple daily insulin injections on the course of diabetic retinopathy. Diabetes 25: 463-469

11. Lavaux JP, Pirart J, Eisendrath C (1975) The course of diabetic retinopathy: a statistical study on its development, progression and regression in 4.400 diabetics. Diabetologia 11: 358 
12. Mirouze J, Selam T L, Pham T C, Cavadore D (1977) Evaluation of exogenous insulin homeostasis by the artificial pancreas in insulin-dependent diabetics. Diabetologia 13: 273-278

13. Morell B, Blatter G, Froesch ER (1978) Einstellung labiler Diabetiker mit einem einfachen Insulin Infusionsprogramm. Schweiz Med Wochenschr 108: 1803-1806

14. Natvig H (1956) Nye høide-vekttabeller for norske kvinner og menn. Landsforeningen for kosthold og helse, Oslo

15. Pfeiffer EF, Beischer W, Kerner W (1977) The artificial endocrine pancreas in clinical research. Horm Metab Res [Suppl] 7: 95-114

16. Pickup J C, Keen H, Parsons J A, Alberti KGMM (1978) Continuous subcutaneous insulin infusion: an approach to achieving normoglycaemia. Br Med J I: 204-207

17. Pickup J C, Keen H, Parsons J A, Alberti KGMM, Rowe AS (1979) Continuous subcutaneous insulin infusion: Improved bloodglucose and intermediary-metabolite control in diabetics. Lancet I: $1255-1258$

18. Pickup J C, Keen H, Parsons J A, Alberti K GMM (1979) Continuous subcutaneous insulin infusion: Good blood glucose control for up to 4 days. Diabetologia 16: 385-389

19. Service FJ, Molnar GD, Rosevear JW, Ackerman E, Galewood LC, Taylor WF (1970) Mean amplitude of glycaemic excursions, a measure of diabetic instability. Diabetes 19: $644-656$
20. Slama G, Hautecouverture M, Assan R, Tchobroutsky G (1974) One to five days of continuous intravenous insulin infusion on seven diabetic patients. Diabetes 23: 732-738

21. Tamborlane WV, Sherwin RS, Genel M, Felig P (1979) Reduction to normal of plasma glucose in juvenile diabetes by subcutaneous administration of insulin with a portable infusion pump. N Engl J Med 300: 573-578

22. Tamborlane WV, Sherwin RS, Genel M, Felig P (1979) Restoration of normal lipid and aminoacid metabolism in diabetic patients treated with a portable insulin-infusion pump. Lancet I: $1258-1261$

23. Tchobroutsky G (1978) Relation of diabetic control to development of microvascular complications. Diabetologia 15 : 143-152

Received: March 19, 1979,

and in revised form: August 28, 1979

Dr. Klaus Kølendorf

Steno Memorial Hospital

DK-2820 Gentofte

Denmark 